\title{
Development of an Indicator Scheme for the Environment Impact Assessment in the Federal District, Mexico
}

\author{
Maria Perevochtchikova ${ }^{1}$, Iskra Alejandra Rojo Negrete $^{2}$ \\ ${ }^{1}$ Center for Demographic, Urban and Environmental Studies, El Colegio de México A.C., Mexico City, Mexico; ${ }^{2}$ Postgraduate in \\ Geography, National Autonomous University of Mexico, Mexico City, Mexico. \\ Email: mperevochtchikova@colmex.mx
}

Received January $12^{\text {th }}, 2013$; revised February $10^{\text {th }}, 2013$; accepted March $2^{\text {nd }}, 2013$

\begin{abstract}
In this work is developed a proposal of environment indicators needed for the Environment Impact Assessment (EIA) process in Mexico's Federal District (FD); through which are authorized the construction and realization of different work actions and activities. The methodology is based on the combination of cabinet and field work, performed in three stages. In the first, a documental review was carried out within the topic of Environment Impact (EI), the EIA and the study area, with a subsequent analysis of the environment indicators at an international, national and regional scale. In the second, the systematization of information was performed for the sixteen study cases at a local scale and the organization and analysis of a data base with the allotted information. And in the last stage, a field work was realized with participative observations in three verification sites and interview applications to the principal actors of the EIA process. These results allowed: to determine the main limitations within the EIA process (methodological, technical and operational), to propose an indicators scheme, and to formulate recommendations focused on the improvement of this Environment Public Policy instrument.
\end{abstract}

Keywords: Environment Impact; Environment Impact Assessment; Environment Indicators; Federal District; Mexico

\section{Introduction}

Since five decades ago the process of recognizing the environmental degradation at worldwide level began, with the publication of Silent Spring [1]. The deterioration process was directly related with the concept of Environment Impact (EI) that refers to the inherent environment consequences regarding the realization of diverse human activities and that require to be forecasted and measured in order to mitigate their negative effects. So, in order to identify and calculate these effects the Environment Impact Assessment (EIA) procedure has been designed [2-4].

The EIA contributes to interpret and evaluate changes and facilitate the communication about the environmental situation in comprehensible and systematized terms for the society in general and for the decision-makers [5-7]. At international level this instrument was fully accepted in 1992 at the United Nations Conference on Environment and Development [4: 2] and nowadays 191 countries of United Nations contemplate this evaluation mechanism within their national policy strategies $[2,4$, 8-10].

In Mexico, the evaluation of environment impact is performed actually on different levels, from federal, state to local competence. As a case study, the main interest was concentrated on the problematic of the Federal District (FD), the capital of the country where everyday many construction works and other projects and activities are being developed and the EIA is becoming an indispensable tool of the environmental public policy. In particular, the Secretary of Environment of the Federal District Government (SE-FDG) is the institutional organ that has within its internal structure the General Direction of Environmental Regulation (GDER) that reviews the EI evaluations presented by the proponents ${ }^{1}$ (promoventes in Spanish), emits the recommendations, supervises and controls its fulfillment. The Direction of Environment Impact Assessment of the GDER, created in recent years, performs analysis of the Risk Studies, Preventive Reports, Environment Impact Manifestations, in general and in specific modalities [12,13].

Nevertheless, as experience has shown, the EIA process in the FD since the start of its implementation in 2007 has faced diverse limitations, of methodological and practical character, mainly by the lack of clear definite methodology, justified scheme of indicators, and

\footnotetext{
${ }^{1}$ The proponent is a physical or moral person that is interested in the development of certain works or activities; that is "promoting" the project [11].
} 
absence of sufficient human and economic recourses, between other causes [14]. For such reason, the objective of this study was concentrated in the improvement of one of these points; particularly in the development of a proposal of indicators scheme that presents an urgent necessity for the environment impact assessment process in FD.

\section{The State of the Art}

\subsection{Environmental Impact Assessment}

The Environmental Impact Assessment (EIA) is defined as a juridical-technical-scientific-administrative tool that helps to identify, predict, evaluate and quantify the environmental effects that a human activity potentially can produce; and that includes the measures of prevention, correction and mitigation of the identified impacts $[3,4$, 15]. The main objectives of the EIA establish: 1) provide to the authorities with the efficient and sufficient information about the effects of each project, in order to evaluate the options about its development and execution; and 2) recommend solutions and mitigation measures within sustainability vision, in economic, social and environmental terms [2,7,16-18].

From the emergence of the National Environmental Policy Act in the USA four decades ago, the EIA mechanism was early adopted by countries, such as Canada, Australia, Sweden and New Zealand, etc. [5]. But, the real world-wide recognition the EIA has had in the last 20 years after the United Nations (UN) Conference on Environment and Development, where it was demonstrated and pronounced the human preoccupation about deterioration level of the planet ecosystems. Other international events helped the EIA to be established at the world political arena; reason why they deserve to be mentioned: the UN Convention on Biological Diversity, the UN Convention on the Law of the Seas, the Convention on Transboundary EIA, the Convention on Wetlands of International Importance, the UN Framework Convention on Climate Change, the Convention on Access to Information, among others. So nowadays 191 countries of the United Nations have incorporated the EIA procedure within their policies and about 180 of these have necessary references in their national legislations $[2,4,19]$.

In Mexico, the EIA adaptation process has been related to the evolution of the environmental legislation and institutions that has had high influence from the international agreements in this matter. Particularly, it is possible to detect three stages in this process: 1) under hygienist approach (1970's), when the Law of the Prevention and the Control of Environmental Contamination, and the Law of the Environment Protection were created; 2) with urban topic (1980's), due to the foundation of
Secretary of Urban Development and Ecology, and the Federal Law of the Environment Protection 1982; and 3) evolution to the integral aims (1990-2000), with presentation of General Law of Ecological Equilibrium and the Environment Protection 1988 (LGEEPA in Spanish abbreviation), and foundation of different environmental institutions, including the National Council of Environment and Natural Resources (SEMARNAT in Spanish), the National Ecology Institute (INE), etc. [11,20]. During this period, diverse policy instruments of environmental protection were created, such as ecology planning, ordering and regulation, EIA ecological investigation and education.

\subsection{Problematic of the EIA}

If could be observed that the EIA has become a key tool of the environmental protection policy. Even, the different specific forms of environmental assessment (EA) are recognized and applied around the world: the Environmental EA $[2,9,10]$, the Strategic EA [21,22], the Social EA [18], the Sustainability Assessment [17,23]; and recently the Health Impact Assessment has emerged [2: 7]. Nevertheless, in Mexico apparently only the term of EIA is handled; when it could be possible to consider the Strategic EA (by its nature) for many cases of evaluation.

On the other hand, it is necessary to highlight that the EIA presents several political and practical limitations, as influences by concrete development government decisions, no consideration of the interests of involved actors, bureaucratic problems, no any interest by the decisionmakers and their professional incapacity, lack of active participation of society, lack of transparency and the needs of international researches in such matter [7: 661-662]. Bond and Pope [24:4] added to these are the following points: poor consideration of cumulative effect, inefficiency of the human resources for adequate realization of the evaluation process, poor consideration of alternatives, and many faults on the dialogue between involved sectors.

But also it is important to mention the methodological problems, reflected in the differences in the used approaches, theoretical perspective and diversity of contexts and resources available to EIA. Particularly, the special interest is taken about the inequity in quality and quantity of used information and due to this, common faults of communication [24]. All these problems are very recognized for the case of Mexico, where the methodological problematic is dragged to the application process [13].

\subsection{Environmental Indicators}

As Vidal and Franco mentioned [15], in the procedure of EIA it is indispensable to integrate and synthesize the 
high volume of information about multiple environmental characteristics that are transformed in indicators. The indicators results our link with the world [25]; that represents an empirical model of reality [26]. They are a parameter or group of parameters that offer and communicate synthetic information about a phenomena or process $[27,28]$.

The use of indicators is broadly divulged in the diverse environmental institutions at international level. For example, the Program of the United Nations for Development [29] has published the indicators of Sustainable Development; and the Organization for Economic Cooperation and Development has presented their environmental indicators for assessing the progress in the environmental state [30]. For the aims of EIA the environmental indicators are representing an important tool, and this could be observed in their use for Strategic Environmental Assessment [31-33]; for Social and Environmental Impact [34]; and for urban planning [35]. At national level, in Mexico, the National Council of Environment and Natural Resources has elaborated basic indicators for the environment performance but not for EIA [36-38].

On the logical "cause-effect" scheme of the OECD [39] Pressure-State-Response, the EI indicators are subdivided in three groups, according to the stage [6]. In Pressure direct drivers (emissions of pollutants and discharges of residual waters) and indirect ones (population growth and gross internal product) are measured. In State it is characterized and diagnosed the environment's situation (air, water, soil, biodiversity). And in Response the indicators and the complex indexes related to the social and political effort and natural resources are presented (Figure 1).

This process is based on the use of great amount of information and its transformation [26]; required distinct human, economic and social resources at the stages. But, of all the ways, the success of the public policy will depend on quality and quantity (sufficiency, efficiency and representatively) of the information obtained from the lowest level helped by monitoring systems; and of the communication capacity between steps.

\section{Case Study}

The Federal District (FD) is the capital of Mexico that

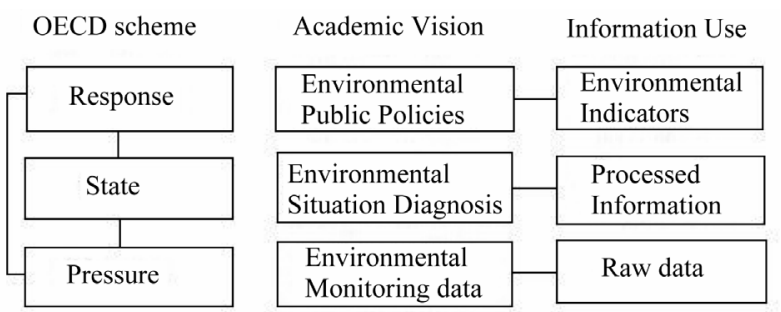

Figure 1. Scheme of the use of information in environment public policy. has grown since the middle of the last century to the grade that at the moment it forms part of the Mexico City Metropolitan Area (MCMA), consolidating itself as a member of the 20 most important megacities of the world and of the four located in Latin America. It is constituted by 16 delegations of the Federal District and at least 35 municipalities of the State of Mexico and one of Hidalgo. The territorial extension of the MCMA is approximately of 4.9 thousand $\mathrm{km}^{2}(0.3 \%$ of the national territory) and the population is around 23 million ( $20 \%$ of the total of the country), according to [40].

As natural space, the MCMA occupies the whole south part of the Valley of Mexico that is a closed watershed with a surface of $9600 \mathrm{~km}^{2}$ and average altitude of 2240 meters above sea level, surrounded by big mountains in its southwest, south and southeast parts. On the other hand the territory of the FD is conformed by $59 \%$ of Conservation Land, which accounts about 87,310 ha with natural vegetation and distributed at the south; and another $41 \%(61,458 \mathrm{ha})$ considered as urban territory (Figure 2).

Mexico City concentrates the political and economic power of the country; with $32 \%$ of the Gross Internal Product generated [41] and where the federal, state and local level institutions are located. The situation that altogether with the population increase, gave rise to the process of urban expansion towards the periphery of the city that transformed the landscape and interferes in the basin's natural regime.

Because of the interaction of the population, the economy, the political and specific geographic factors, the complex city problematic is produced; which is reflected in social and economic problems, besides the environmental deterioration with air, water and soil pollution, soil compacting, modification of hydrological cycle, etc. This situation directly affects: the human and ecosystem health, the infrastructure, the increase of the economic costs to repair these damages, and the provocation of social conflicts. Reason for which it is indispensable to implement new public policies, cradled in the assessment and prevention of the environmental impact, based on the representative indicators at local level that can consider the specific problematic of each territory.

\section{Methodology}

Gómez-Navarro et al. [35] have mentioned seven steps in the development process for an environmental pressure index for sustainable urban planning. Particularly, the proposal of indicators that finally forms parts of the complex index, including fazes, as statement of the problem, selection of a panel of experts, determination of the alternatives, selection of the criteria (pressure indicators), evaluation problem, prioritization of alternatives, and analysis of results. On the matter Donnelly et al. [31] 


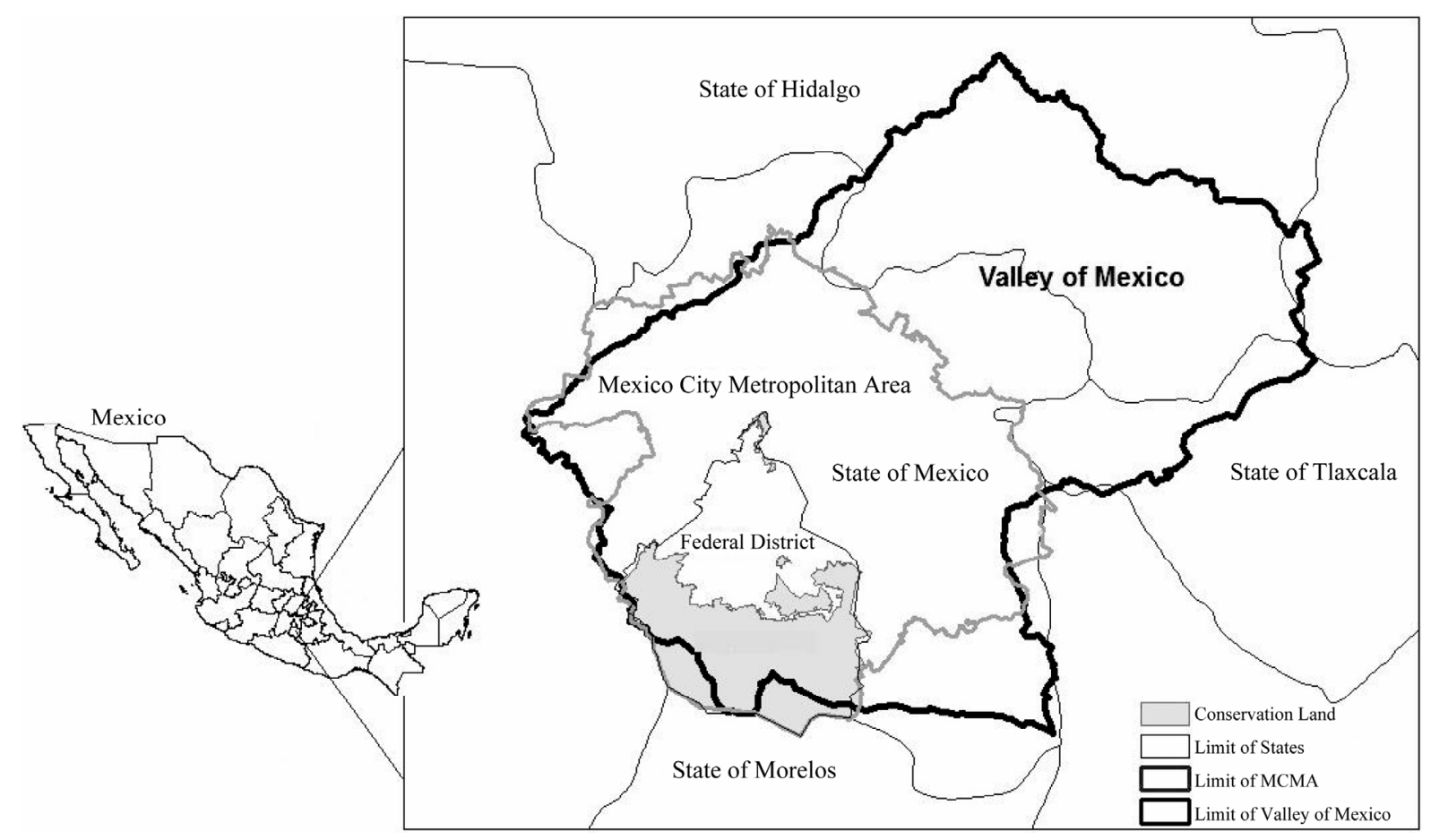

Figure 2. Valley of Mexico, Federal District and MCMA (source: based on [40]).

have demonstrated the effectiveness of a workshop-based approach to develop appropriate criteria for selecting environmental indicators for use in Environmental Assessment.

Additionally, it is necessary to say that the existence of the large number of indicators sets at international and national levels is not stopping the creation of a new and local indicator [33: 4]. On the contrary it is essential to consider the previous experience at different levels, because it could be useful in providing important data resource and methodologies for indicator development [31].

Based on this, it was decided to carry out this work in three stages (steps) by means of the combination of cabinet and field work:

- In the first stage the recompilation of information and the bibliographical revision inside the topic and area of interest were performed; and the analysis of existing environmental indicators at international, regional and national levels was done.

- In the second step the information at a local level was systematized and analyzed, which was supplied by the Direction of Environment Impact Assessment (DEIA) of the SE-FDG regarding to Risk Studies, Preventive Reports, Environmental Impact Manifestations, authorization resolutions; and a database was elaborated with information of 16 case studies. Also the federal and local juridical and normative support information was revised and analyzed in virtue of its usefulness for the project.
- At last, a scheme of environment indicators was developed, consulted and evaluated on one workshop (with the attendance of the multi-disciplinary group of specialists in the matter and decision-makers at national and FD levels) that later was tried in practice application; and a Geographical Information System was used for constructing the maps and visualizing the use of proposed indicators.

Thanks to the favorable disposition of the personnel of the DEIA of the Federal District Government (SE-FDG) it was possible to consult some files of the environmental impact evaluations carried out by the Sub-direction of Evaluation; and to perform proof interviews with them; to invite them to the workshop and to visit three evaluation cases in situ. In total 16 files were consulted with permission of the DEIA (five and six cases per administrative unit), available in printed and/or digital format that were distributed in equitable form between the small and big projects; and in the space.

\section{Observations}

\subsection{The EIA Process in the FD}

In the FD diverse works of housing, infrastructure and roads construction, services and other activities are constantly developed. Those are mainly of private capital, with the relatively low proportion of public works, with a marked difference between the private funds taking part in the construction industry in the urban territory and the public ones applied in the Conservation Land (where the 
common land property predominates).

Due the influence of the creation at the federal level of the General Direction of Environmental Impact and Risk in 2003 [42], it was pronounced al local level in 2007 the incorporation of the General Direction of Environmental Regulation (GDER) within the structure of Secretary of Environment of Federal District Government [12: 11-12]. Ones of the new substructures that composed this institutional scheme have been the Direction of the Environmental Impact Assessment (DEIA) and its Sub-direction of Evaluation (SDE); based on the juridical-administrative frame formed by the Mexican Constitution, the FD Government Statute and some federal and local Laws, Codes, Regulations and Norms $[12,13]$.

In this way the SDE of the DEIA has acquired the functions to emit the resolutions in the matter of EIA and to follow up their fulfillment [13]. This department is subdivided in three units in virtue of profile of the analyzed works and activities: Directive Unit (DU) of Industry and Services; DU of Housing Development; and DU of Projects on Conservation Land [13: 51-52].

The EIA process begins with an application form that the proponents present, or that alternatively, it can be impelled as a demand of the ED-FDG, in answer to the realization of a work without authorization. Depending on the work type and/or activity and their potential impacts, it is either presented a Preventive Report, an Environment Impact Manifestation (EIM), in general or specific modality, or a Risk Study. Usually, these studies are carried out by external consultancy service; and legally doesn't exist a definition of the professional profile nor Census of specialists required for this process. That represents a problem, because the characteristics of EIA demand a use and analysis of high volume of information; that must be performed only by a multidisciplinary group.

This situation caused the inequity in the quality and contents of the studies and reports; which together with the big number of EIM and less available time to this make impossible the adequate evaluation and communication. On the other hand, because of the absence of clearly defined indicators, it is not possible to realize comparisons between the stages of the development of the projects for determining the impacts, doing the followup and controlling them.

\subsection{International Indicators}

As it was mentioned, the environment indicators are considered powerful tools for the decision making in the evaluation of environmental performance $[30,32,34]$. The use of the environment indicators so thoroughly diffused at international level, as the product of the extraordinary interest exists in the development of an instrument that allows measuring the advances of the actions guided towards sustainable development. In the last decade, in industrialized and developing countries (although in a smaller measure), diverse institutions and organisms have developed indicators [33].

According to the International Institute of the Sustainable Development (IISD), around 840 proposals of indicators have been registered in the compendium $[25,43]$. Between the more popular proposals of environmental indicators (that include the topics such as air, water, soil, vegetation, etc.) are from the World Bank [44], the European Environment Agency [45], the OECD [30,46], and the Commission for Sustainable Development of the United Nations [28]. However, the problems that frequently face the development and use of information are usually related with a diversity of focuses, used methodologies, objectives and spatial and temporal scales; besides the marked differences in the data availability, a lack of homogeneity, continuity, validation and integration of the natural, social and economic aspects $[28,45$, 47,48].

On the part of regional indicators it could be said that the countries of North America have adopted the causality focus of the OECD and the thematic too (by specific themes) in the development of environmental indicators. Particularly, the common themes that all share are: air, water, biodiversity, climate change, forests and soils; to which other topics are added in accordance with the specific necessities of each country [13].

\subsection{National Indicators}

The experience of the development of environmental indicators in Mexico goes back to 1993, when the National Ecology Institute (NEI) through its participation in the North American Workshop of Environmental Information, together with the Environment Protection Agency of Canada and the North American Environmental Protection Agency, presented their study "An Approach Towards Environmental Indicators for Mexico", where it were established the conceptual bases for the development of environmental indicators in the country [49].

Later on, in 1997 the first advances of indicators were published using the outline of the OECD "PressureState-Response" (PSR), with some modifications that incorporated the international experiences in the subject [50]. This work continued with The Evaluation of the Environmental Performance, Report 2000, where it was worked the concept of integrating a system of environmental indicators [51]. In this publication, the actualizations of indicators contained in the report of 1997 were included and new topics were incorporated: water, forests, soils and fishing; the PSR model stayed and was procured to establish the relationship of the atmosphere 
with the productive sectors [52].

Then by the year 2003, the Report of the Environment Situation in Mexico and in 2008 the Basic Indicators of the Environmental Performance were published $[36,37]$. This work contains nearly 140 indicators and other 450 complementary variables, with which is sought to give a proof vision about the environment state of the country.

At the local level it is necessary to mention the publication of López and Rodríguez [53] with a compilation of works about the Concepts and Application of Environmental Indicators and of Sustainability in Mexico, where academics of diverse educational institutions of the country and representatives of the public and government sector participated.

\subsection{Local Indicators Scheme Proposal}

From this previous revision, it was continued with the following thematic groups of criteria to develop our scheme of indicators: air, water, solid residuals, vegeta- tion, soil, energy and socio-economic aspects. Within the proposal it was considered the existing experience at international and national levels on the indicators; that was proof-revised in according to its substantiality and availability of information at Federal District level.

A preliminary scheme of indicators was consulted and evaluated on one workshop, to which the multi-disciplinary team of a total of 20 specialists in the matter of EIA and the decision-makers at national (SEMARNAT) and FD (DEIA) levels attended. The indicators were obtained regarding the opinion of their importance in scale from 0 as the minimum to 5 as the maximum; and as a result, the proposed ones with evaluation lower than 3.5 were eliminated. Later the modified scheme was returned to consult with the directive personnel of the SDE of DEIA to fit the specific needs of the units. And finally a scheme of common indicators for three Directive Units was defined (see Table 1).

To sustain this proposal in terms of magnitude of the

Table 1. Proposed environmental indicators.

\begin{tabular}{|c|c|c|c|c|}
\hline Thematic area & Subject & Sub-subject & Environmental indicator & Measurement unit \\
\hline \multirow{6}{*}{ Air } & \multirow{6}{*}{ Contamination } & \multirow{5}{*}{ Emisions } & $\mathrm{CO}_{2}$ & $\mathrm{Kg}$ Tot \\
\hline & & & $\mathrm{NO}_{\mathrm{X}}$ & $\mathrm{Kg}$ Tot \\
\hline & & & $\mathrm{SO}_{\mathrm{x}}$ & $\mathrm{Kg}$ Tot \\
\hline & & & $\mathrm{PM}_{10}$ & $\mathrm{Kg}$ Tot \\
\hline & & & $\mathrm{HC}$ & $\mathrm{Kg}$ Tot \\
\hline & & Auditive & Noise & dB Max \\
\hline \multirow{7}{*}{ Water } & \multirow{4}{*}{ Quantity } & Potable water & Potable water use & $\mathrm{m}^{3}$ Tot \\
\hline & & \multirow{3}{*}{ Residual Water } & Residual water production & $\mathrm{m}^{3} / \mathrm{s}$ \\
\hline & & & Residual water use & $\mathrm{m}^{3} / \mathrm{s}$ \\
\hline & & & Residual water re-use & $\%$ \\
\hline & \multirow{3}{*}{ Quality } & \multirow{3}{*}{ Descharge } & SDT & $\mathrm{mg} / 1$ \\
\hline & & & DQO & $\mathrm{mg} / \mathrm{l}$ \\
\hline & & & DBO & $\mathrm{mg} / 1$ \\
\hline \multirow{5}{*}{ Trash } & \multirow{4}{*}{ Industry } & \multirow{2}{*}{ Construction Residue } & Total production & $\mathrm{m}^{3}$ \\
\hline & & & Recycling & $\%$ \\
\hline & & \multirow{2}{*}{ Danger and Toxic Residue } & Production & $\mathrm{Kg}$ \\
\hline & & & Recycling & $\%$ \\
\hline & Organic & Residues & Production & $\mathrm{Kg}$ Tot \\
\hline \multirow{2}{*}{ Vegetation } & \multirow{2}{*}{ Trees } & Quantity & Trees & number \\
\hline & & Environmental Value & Assigned points & points \\
\hline \multirow{4}{*}{ Soil } & Use & Land Use Modification & $\%$ Surface of construction over total & $\%$ \\
\hline & \multirow{3}{*}{ Degradation } & Compactation & Speed & $\mathrm{sm} /$ year \\
\hline & & Erosion & Erosion Index & without unit \\
\hline & & Contamination & Acidification & $\mathrm{pH}$ \\
\hline \multirow{2}{*}{ Energy } & \multirow{2}{*}{ Use } & Alternative Energy Use & $\%$ Alternative energy & $\mathrm{kW}$ \\
\hline & & Energy & & KW Tot \\
\hline
\end{tabular}


environmental impacts the juridical-normative frame was proof-revised. It is necessary to say that the practice of the EIA in the Federal District is governed legally by the Constitution. From which comes off the pertinent laws for the conservation and for the sustainable development; where the main one is the General Law of the Ecological Equilibrium and Environmental Protection, which even determines the steps and procedures for the EIA in Mexican territory. The laws, regulations and therefore plans and programs operate at two scales; federal and local (with the juridical center at state level of the Environmental Law and its Regulation) contemplate, demand and contribute to the evaluation of the environmental impact. Additionally, there are the Mexican Official Norms (NOM) that establish the standards in the units and the protocols of the measurement and the maximum permissible limits for pollution characteristics.

In this sense, diverse lacks, inconsistencies and delays of conceptual, methodological and technical aspects were found. Even, the federal laws and their regulations are ambiguous, not articulated, without methods or scientific background. At local scale, although there are certain advances in environmental legislation, the problems are the same, with great misdirection in the operative part. The biggest deficiencies are in the normativity of the environmental components values, where it is evident the inclination toward topics, as the air quality and sound contamination, continued by water and residuals, with very less development of the themes such as soil, green areas and energy [13].

\subsection{Application of Proposed Indicators Scheme}

In order to visualize the potential use and prove in practice the proposed scheme of indicators, it was performed the systematization of information from the files of the environmental impact evaluations carried out by the SubDirection of Evaluation of DEIA; a database was elaborated and a Geographical Information System was constructed for selected 16 cases (see Figure 3).

The information about the cases, which it was proportioned by DEIA, incorporated 5 files from DU of Industry and Services, 6 from DU of Housing Development and 5 of Projects on Conservation Land; distributed equitably between small and big projects (from a construction of a gas station to a highway or a group of conservation activities); and between the approved cases and the ones in process of authorization. Because of the confidentiality of the data, it isn't possible to present more details on the matter.

Nevertheless, from the revision of archives, the following common problematic was detected within the process of the EIA in the FD:

- The presented information is very heterogeneous and

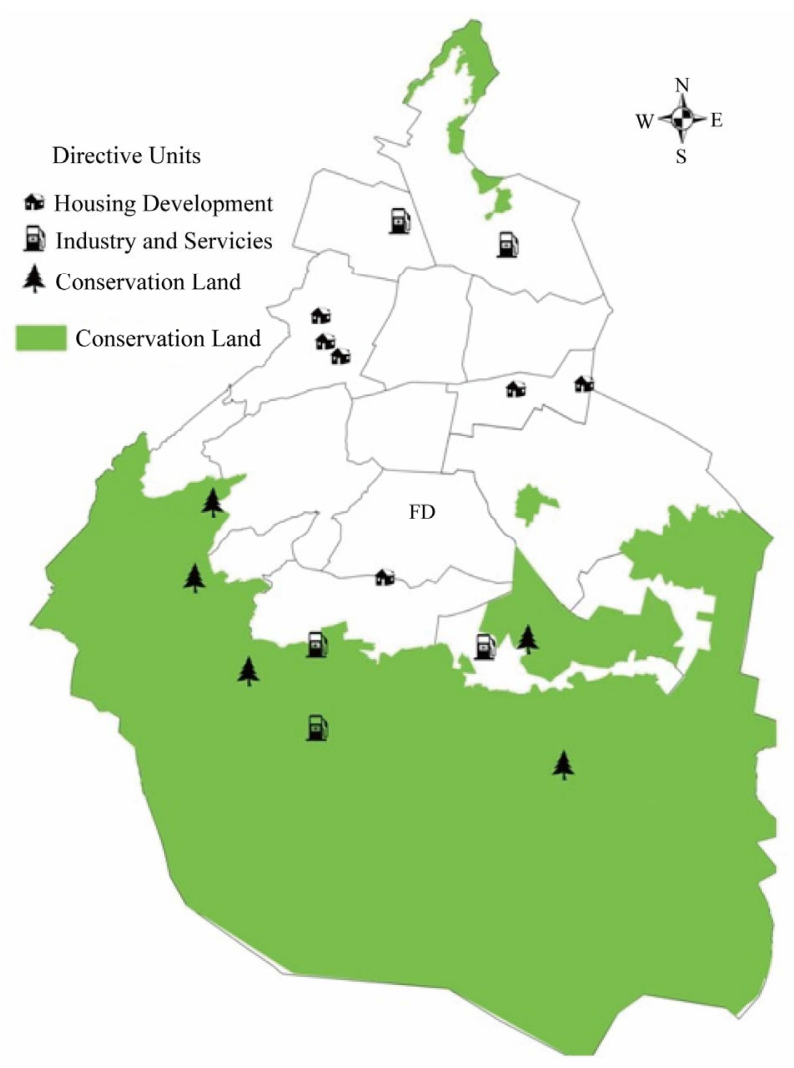

Figure 3. Site location of the study cases (source: files of the SDE, DEIA).

scarce; in many cases is minimum and qualitative (until the description of type "good" or "bad quality").

- The used methodologies are very heterogeneous, with very diverse and incomplete techniques; in its majority based on the Matrix of Leopold et al. [54].

- Without diagnostic, nor characterization of the environment impacts to happen, nor solutions to be implemented by stages of the work development.

- In the majority reports are not based nor supported in the current normativity.

- Not always include all the stages of the work construction (site preparation, construction, operation and abandonment).

- Practically without any use of criteria and/or tangible, reliable and measurable indicators; only some aspects are mentioned, such as air, water, vegetation and soil.

- In many cases, the construction works were approved without revision and sometimes outside of the law (mainly for the times required by the EIA).

Under these limitations and with the very little information recovered from the consulted reports, the intent to systematize the data was done, starting from geo-reference of information of each project. For that, two available tools of the Geographical Information System (GIS) were employed: Google Earth and Arc GIS. In particular, with the navigator of Google Earth, general panorama of 
the location of the 16 projects was consulted on-line, with organized and deployed data as images. In the case of the Arc GIS software, it was possible to manage all the information in the form of interactive tables, which also allowed to show spatial distribution of specific aspects (as points, lines and/or polygons) and to build thematic maps; grouping the data by stage of the project development, as Stage I: site preparation and construction, Stage II: op- eration and abandonment of site (see Tables 2 and 3).

With these two databases (subdivided by development stages) were realized the thematic maps only for some of the proposed indicators due to the availability of information in the case files. In particular, in the Figure 4 it can be observed the location of the 16 projects with respective values of noise, solid construction residuals and cut trees for the Stage I; where a range of traffic light

Table 2. Table of indicators of Stage I (source: archives of SDE, DEIA).

\begin{tabular}{|c|c|c|c|c|c|c|c|c|c|c|c|c|c|c|}
\hline $\begin{array}{c}\text { Project } \\
\text { code }\end{array}$ & $\mathrm{CO}_{2}$ & NOX & SOX & Noise & $\begin{array}{c}\text { Potable } \\
\text { water }\end{array}$ & $\begin{array}{c}\text { Residual } \\
\text { water }\end{array}$ & $\begin{array}{l}\text { Trate } \\
\text { water }\end{array}$ & $\begin{array}{l}\text { T.w. } \\
\text { re-use }\end{array}$ & $\begin{array}{l}\text { Constr. } \\
\text { residue }\end{array}$ & $\begin{array}{l}\text { Recycling } \\
\text { c.r. }\end{array}$ & $\begin{array}{l}\text { Recicling } \\
\text { d.r. }\end{array}$ & $\begin{array}{l}\text { Organic } \\
\text { residue }\end{array}$ & $\begin{array}{l}\text { Recycling } \\
\text { o.r. }\end{array}$ & Trees \\
\hline 1 & & & & 68 & 221,920 & & & 58 & 4710 & 90 & & & & 19 \\
\hline 2 & & & & & & & & & 18 & & & 17 & & \\
\hline 3 & & & & 85 & 39,754 & & 250 & & 12 & & & & & 7 \\
\hline 4 & & & & 100 & 151 & & & & & & & & & \\
\hline 5 & & & & & 584 & & 1680 & & & & & 58 & & 5 \\
\hline 6 & & & & 68 & & & & & 78 & & & 1 & & 0 \\
\hline 7 & & & & 95 & & & 1260 & & 42 & & & 14 & & \\
\hline 8 & $3,345,000$ & 52,000 & & 96 & 20,200 & & 5000 & & 589,459 & 21 & & & & 2099 \\
\hline 9 & $\mathrm{NC}$ & $\mathrm{NC}$ & & 105 & 1933 & 1546 & 864 & 54 & 229 & 75 & & & & 9 \\
\hline 10 & & & & 65 & 745 & & & & & & & & & \\
\hline 11 & 22,128 & 10,241 & 1577 & 75 & & & & & 414 & 50 & 51 & 76 & 51 & \\
\hline 12 & $5,968,000$ & 65,000 & & 96 & 5700 & & 1400 & & 122,199 & 99 & & & & 5322 \\
\hline 13 & 0 & 0 & 0 & 80 & 92 & & 20 & & 300 & & & & & \\
\hline 14 & & & & 89 & 193 & & & & 1596 & 11 & & & & 0 \\
\hline 15 & & & & 80 & 36 & & & & & & & & & \\
\hline 16 & 24 & 474 & & 97 & & & & & 4 & & & 30 & & 49 \\
\hline
\end{tabular}

Table 3. Table of indicators of Stage II (source: archives of SDE, DEIA).

\begin{tabular}{|c|c|c|c|c|c|c|c|c|c|c|c|c|c|c|c|}
\hline $\begin{array}{c}\text { Project } \\
\text { code }\end{array}$ & $\mathrm{CO}_{2}$ & NOX & SOX & PM10 & $\mathrm{HC}$ & Noise & $\begin{array}{l}\text { Potable } \\
\text { water }\end{array}$ & $\begin{array}{c}\text { Residual } \\
\text { water }\end{array}$ & $\begin{array}{l}\text { Trate } \\
\text { water }\end{array}$ & $\begin{array}{c}\text { T.w } \\
\text { re-use }\end{array}$ & $\begin{array}{l}\text { Constr } \\
\text { residue }\end{array}$ & $\begin{array}{l}\text { Recycling } \\
\text { c.r. }\end{array}$ & $\begin{array}{l}\text { Danger } \\
\text { residue }\end{array}$ & $\begin{array}{l}\text { Recicling } \\
\text { d.r. }\end{array}$ & $\begin{array}{l}\text { Organic } \\
\text { residue }\end{array}$ \\
\hline 1 & & & & & & 65 & 75,190 & 64,605 & 64,605 & 100 & & & & & 857 \\
\hline \multicolumn{16}{|l|}{2} \\
\hline \multicolumn{16}{|l|}{3} \\
\hline \multicolumn{16}{|l|}{4} \\
\hline 5 & & & & & & 68 & 276 & 584 & & & & & & & \\
\hline 6 & & & & & & & 8 & 1460 & 2 & & & & 984 & & \\
\hline 7 & & & & & & 70 & 2860 & & & & & & & & 1 \\
\hline 8 & $-12,973,000$ & $-101,000$ & & 1000 & & 90 & 20 & & & & & & & & \\
\hline 9 & $\mathrm{NC}$ & $\mathrm{NC}$ & & & & 68 & 11,717 & 11,037 & & 20 & & & & & \\
\hline 10 & & $\mathrm{NC}$ & $\mathrm{NC}$ & $\mathrm{NC}$ & $\mathrm{NC}$ & & 27,813 & & 27,813 & & & & & & \\
\hline 11 & $-188,980$ & & & & & 80 & -2969 & & & & & & & & \\
\hline 12 & $-2.86 \mathrm{E}+09$ & $-2.1 \mathrm{E}+07$ & $-2 \mathrm{E}+06$ & & $-3 E+06$ & 73 & & & & & 8 & 124 & & & \\
\hline 13 & & & & & & & 2054 & & 158 & & & & & & \\
\hline 14 & & & & & & 65 & 3650 & & 1314 & & & & 5 & & 11 \\
\hline 15 & & & & & & 65 & 1825 & & & & & & & 13 & \\
\hline 16 & & & & & & 70 & & & & & & & & & \\
\hline
\end{tabular}



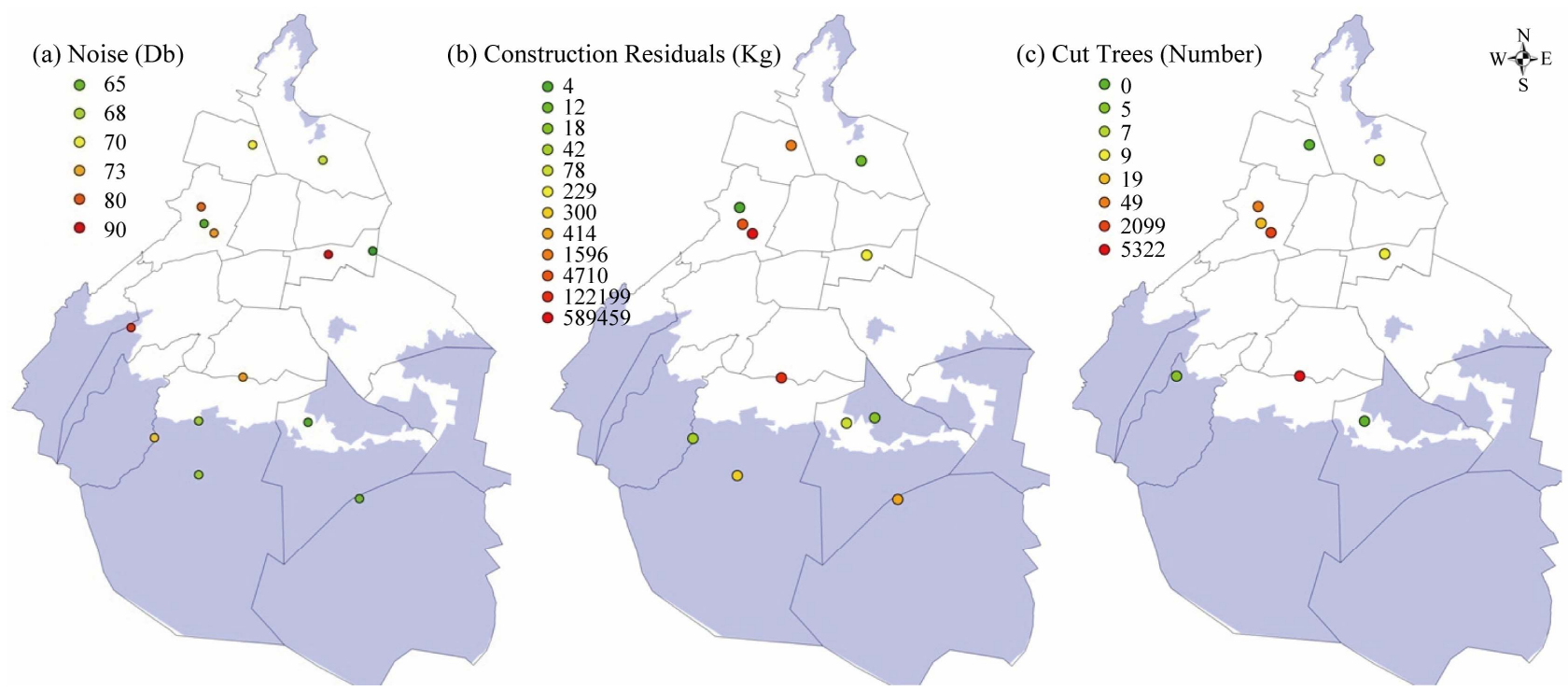

Figure 4. Values of noise (a); construction residuals (b) and cut trees (c) of Stage I.

colors are used to show the impact ranges for this characteristics, from the lowest (green) to concerning (yellow) and to higher (intense red).

With this input it is possible to present the environmental changes by means of comparisons between the values of each evaluated environment component at different stages of the activities or works development, like it is observed in Figure 5 for values of noise in 16 points of the projects.

However, it is necessary to comment that in order to determine the magnitude of an environmental impact; it is required to know the "baseline", or starting point that refers to the environmental situation before the work development or other activity $[6,55]$. For this it is indispensable to have several thematic maps elaborated previously; where by means of interpolation, it could be detected the initial values of the proposed indicators. In this case it would be necessary to also cover the characteristic of significance of the observed impacts; however, this is not yet possible to make under the existing outlines of the EIA in the DEIA; due to the absence of viable, clear and transparent mechanisms of the society participation in general.

On the other hand, the documental investigation of the 16 study cases has been accompanied by a field work, where three technical visits of control were carried out to the sites of different projects, with application of interviews to the main involved actors in the process of the EIA (one site per each administrative unit). These visits had, as a main objective, to verify the data presented in the application to the Sub-Direction of Evaluation on behalf of the entity such as boundaries and location of the property, and the certainty of the information of the impact studies. Unfortunately, it must be noted that because of the limited physical capacities of the ES-FDG, not all the presented cases for the environment impact assessment are visited; for what it is necessary to revise the follow-up process and verification of the execution of suggestions emitted in the resolutions.

\subsection{Detected Problems}

The problems that face the process of the EIA in the FD are multiple and interfere directly in the objectives of the environmental public policies in the sense of the impossibility to achieve the goals of a sustainable development. In specific, the methodological limitations go from the complexity of the process and necessity of an interdisciplinary work that often doesn't exist; to the great diversity of methodologies and used techniques; the duplicity and voids within the juridical-normative settings at national and state scale; coordination absence among dependencies; lack of a common scheme of environmental indicators at local level; the technical and conceptual limitations of the few existing criteria (related with formation type, interpretation and use).

On the other hand, inside the administrative step of the EIA and its practical application, it is very common to find the following inconsistencies: not all cases are visited by SE-FDG personnel; the cases that are visited do not fulfill the time requirements foreseen by the EIA for such stage and necessary to make proof observations; the cost of the technical consultancies is much higher than what is established by law; the certification of consultancy enterprises do not exist, which implies differences in the quality of the presented reports; the presented information is very heterogeneous; the omissions and inconsistencies are in the revisions of the proposed projects; very frequently infringe the established proce- 

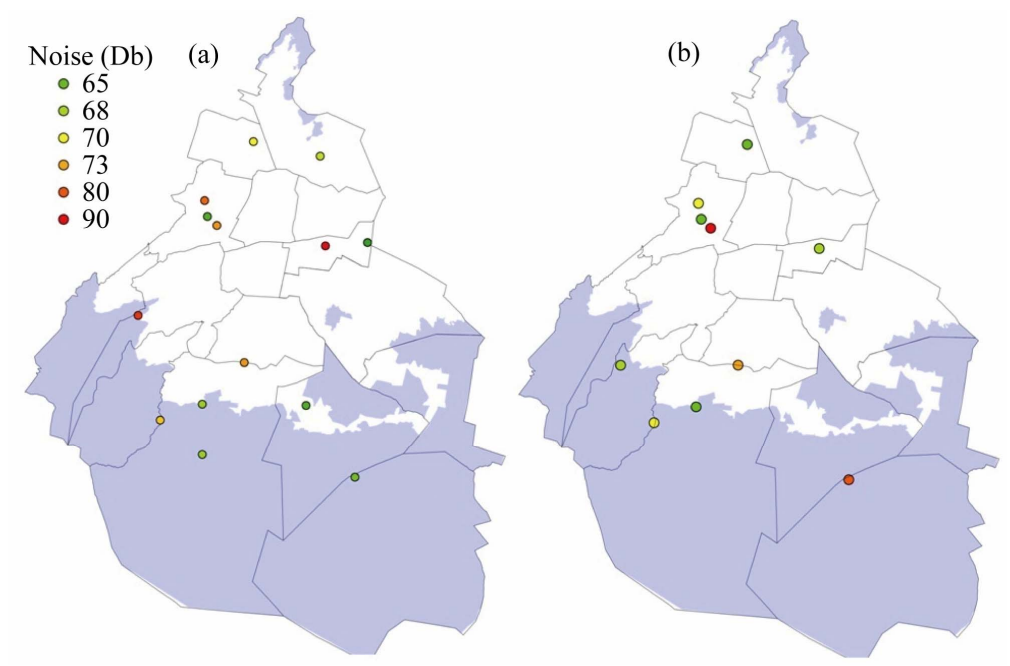

Figure 5. Maximum noise levels at I (a) and II (b) stage of the projects.

dures for the field visits; the socio-cultural and historical impacts are not part of the EIA revisions; it is evident the disinterest of other involved authorities (besides the SEFDG) in the EIA process; it is notorious the interest of the proponents in obtaining the highest financial earnings in the least time possible and without considering social and environmental costs at medium and large time scale.

\section{Conclusions and Recommendations}

The environmental indicators constitute the very useful and popular tool of the environmental public policies, in specific of the analysis of environmental situation, its changes and environment impact assessment. For the meaning of the term of simplifying the complexity, the indicators have taken relevance and quick importance at world-wide level. But their development and implementation have not been easy, because they should be based on sufficient and efficient data and required an interdisciplinary and inter-institutional approach. The important thing in this process is to understand that a unique model of indicators scheme does not exist, due to the structural and functional differences among specific systems, as well as the dynamics of change of the same ones.

As it has been observed throughout the study, the process of the EIA, of socio-political character, in the Federal District has faced multiple limitations and deficiencies of methodological, technical, operational and juridical-normative character that on the whole have evidenced the existent voids in the environmental administration and have determined the necessity for the improvement of this tool. Given their deficiencies, a series of recommendations (or challenges) were formulated for strengthening the professional capacities of the involved actors, from public officials to the proponents to the technical consultants; that required:
- A revision and adjustment of the current legislation and normativity at federal and FD scale to establish the priorities in the juridical sustenance for the environmental indicators (not only for the "pressure" type indicators within the outline of the OECD, but also for "state" type indicators of environmental situation); with which can be obtained "importance" ranges to the proposed indicators.

- An implementation of the certification of the consultancies that elaborate technical reports of environmental impact; improving their professional quality and ethics.

- Improvement of professional capacity of the personnel of the SE-FDG while strengthening their infrastructure; with more financial investment for the support.

- Including within the process of the EIA, a transparent and effective mechanism for the public consultation and rendition of accounts; with the purpose of incurporating the third dimension of environmental impact, the one of "significancy".

- A methodological and technical unification of the EIA process; with development of specific Guidelines for different types of work; and a promotion of the use of simulation models and systems of geographical information. All of this with the purpose of avoiding the "dragging effect" of the methodological and technical problematic in the political process.

- A organization of a "databank" of existing information (inter- and intra-institutional database) in order to facilitate the evaluating procedure.

- Promotion of the usage of the unified scheme of indicators in all cases of the EIA process.

- Differentiation and establishment of the complete EIA procedure only for the works of high magnitude of impact; helped in Strategic Environmental Assess- 
ment.

With all this, the intention is to change the current thinking of "pressure" towards the other step within the process of application of environmental public politics, directed to the evaluation of the environmental "state" and the search for an appropriate "response", effective and viable for decreasing the current ecological deterioration. So that all work, project or human activity will not be approved under the shade of corruption, political pressure, or the ignorance of the importance of such environment topic.

\section{Acknowledgements}

We thank the National Council of Science and Technology and the Institute of Science and Technology of the Federal District for financing the project 120980 from Mixed Funds CONACYT-GDF. Our special thanks to the personnel of the Department of Environment Impact Assessment of the ED-FDG for their disposition and support; to Rosa Osorio, Adrián Vázquez, Algeria Tiburcio, Víctor Jimenez and to Pierre André for their contributions to the project; also to anonym prereviewers for their excellent comments; and to Alex Fehér for translation of this text.

\section{REFERENCES}

[1] R. Carson, "Silent Spring," Houghton Mifflin Company, Boston, 1962.

[2] R. K. Morgan, "Environmental Impact Assessment: The State of the Art," Impact Assessment and Project Appraisal, Vol. 30, No. 1, 2012, pp. 5-14.

[3] IAIA, "EIA Follow-Up. International Best Practice Principles," Special Publication Series No. 6, 2007. www.iaia.org

[4] IAIA, "What Is Impact Assessment?" 2009. www.iaia.org

[5] C. Wood, "Environmental Impact Assessment. A Comparative Review," 2nd edition, London, Prentice Hall, 2003.

[6] P. André, C. E. Delisle and J. P. Revéret, "Environmental Assessment for Sustainable Development: Processes, Actors and Practice," Presses Internationales Polytechnique, Montreal, 2004.

[7] S. Nooteboom, "Impact Assessment Procedures for Sustainable Development: A Complexity Theory Perspective," Environmental impact Assessment Review, Vol. 27, No. 7, 2007, pp. 645-665. doi:10.1016/j.eiar.2007.05.006

[8] J. Weston, "EIA, Decision-Making Theory and Screening and Scoping in UK Practice," Journal of Environmental Planning and Management, Vol. 43, No. 2, 2000, pp. 185-203. doi:10.1080/09640560010667

[9] S. Jay, C. Jones, P. Slinn and C. Word, "Environmental Impact Assessment: Retrospective and Prospect," Environmental Impact Assessment Review, Vol. 27, No. 4, 2007, pp. 287-300. doi:10.1016/j.eiar.2006.12.001
[10] A. J. Sinclair, A. Diduck and P. Fitzpatrick, "Conceptualizing Learning for Sustainability Environmental Assessment: Critical Reflections on 15 Years of Research," Environmental Impact Assessment Review, Vol. 28, No. 7, 2008, pp. 415-428. doi:10.1016/j.eiar.2007.11.001

[11] R. A. Becerra, "La Evaluación del Impacto Ambiental en México. Situación actua y Perspectivas Futuras,” 2012. http://www.ceja.org.mx/IMG/pdf/Situacion_actual.pdf

[12] GDF, "Gaceta Oficial del Distrito Federal 12-06-2008," N 354, 2008. www.ordenjuridico.gob.mx/

[13] SMA-GDF, “Trámites y Servicios de Regulación Ambiental," Distrito Federal, México, Secretaría de Medio Ambiente, 2009.

[14] COLMEX, "Desarrollo de Indicadores Ambientales a Nivel Local para la Evaluación de Impacto Ambiental: Caso Distrito Federal,” Informe Final, COLMEX, UNAM, 2011.

[15] E. Vidal de los Santos and J. Franco López, "Impacto Ambiental. Una Herramienta Para el Desarrollo sustentable," México, AGT Editor, 2009.

[16] D. G. Orea, "Evaluación del Impacto Ambiental. Un Instrumento Preventivo para la Gestión Ambiental," Mundi Prensa, Madrid, 2003.

[17] B. A. Morrison-Sounders and J. Pope, "Sustainability Assessment: The State of the Art," Impact Assessment and Project Appraisal, Vol. 30, No. 1, 2012, pp. 53-62. doi:10.1080/14615517.2012.661974

[18] A. M. Esteves, D. Franks and F. Vanclay, "Social Impact Assessment: The State of the Art," Impact Assessment and Project Appraisal, Vol. 30, No. 1, 2012, pp. 34-42. doi:10.1080/14615517.2012.660356

[19] J. Pope, A. Morrison-Saunders and D. Annandale, “Applying Sustainability Assessment Models," Impact Assessment and Project Appraisal, Vol. 23, No. 4, 2005, pp. 293-302. doi:10.3152/147154605781765436

[20] INE-SEMARNAP, "La Evaluación del Impacto Ambiental. Logros y Retos Para el Desarrollo Sustentable 1995-2000,” México, SEMARNAP, 2000.

[21] M. F. Tetlow and M. Hanusch, "Strategic Environmental Assessment: The State of the Art," Impact Assessment and Project Appraisal, Vol. 30, No. 1, 2012, pp. 15-24. doi:10.1080/14615517.2012.666400

[22] O. Bina, "A Critical Review of the Dominant Lines of Argumentation on the Need for Strategic Environmental Assessment," Environmental Impact Assessment Review, Vol. 27, No. 7, 2007, pp. 585-606. doi:10.1016/j.eiar.2007.05.003

[23] R. Gibson, "Sustainability Assessment: Basic Components of a Practical Approach," Impact Assessment and Project Appraisal, Vol. 24, No. 3, 2006, pp. 170-182. doi: $10.3152 / 147154606781765147$

[24] Bond and J. Pope, "The State of the Art of Impact Assessment in 2012," Impact Assessment and Project Appraisal, Vol. 30, No. 1, 2012, pp. 1-4.

[25] IISD, "Beyond Delusion: A Science and Policy Dialogue on Designing Effective Indicators for Sustainable Development," Seminar Inform, 1999. 
[26] H. Adrianse, E. Rodenburg, D. Bryant and R. Woodward, "Environmental Indicators: A Systematic Approach to Measuring and Reporting on Environmental Policy Performance in the Context of Sustainable Development," World Resource Institute, Washington DC, 1995.

[27] Organisation for Economic Co-Operation and Development, "Towards Sustainable Development: Environmental Indicators," OECD, Paris, 1998.

[28] ONU, WWAP, "1er Informe de las Naciones Unidas sobre el Desarrollo de los Recursos Hídricos en el Mundo: Agua para Todos, Agua Para la Vida," UNESCO y Berghahn Books, Nueva York y Oxford, París, 2003.

[29] PNUD, "Indicators of Sustainable Development: Guidelines and Methodologies," United Nations, 2007.

[30] Organisation for Economic Co-Operation and Development, "OECD Environmental Indicators. Towards Sustainable Development," OECD, Paris, 2001.

[31] Donnelly, M. B. Jones, T. O'Mahony and G. Byrne, "Selecting Environmental Indicator for Use in Strategic Environmental Assessment," Environmental Impact Assessment Review, Vol. 27, No. 2, 2006, pp. 161-175. doi:10.1016/j.eiar.2006.10.006

[32] Donnelly, M. B. Jones, T. O'Mahony and G. Byrne, "Decision Support Framework for Establishing Objectives, Targets and Indicators Doe Use in SEA," Impact Assessment Project Appraisal, Vol. 24, No. 2, 2006, pp. 151157. doi: $10.3152 / 147154606781765246$

[33] J. Gao, "Comparative Study of SEA Experiences between EU and China: The Use of Indicators," Proceedings of EASY-ECO Conference on Sustainable Development Evaluation in Europe, Brussels, 17-19 November 2010, pp. 1-13. http://www.wu.ac.at/inst/fsnu/brussels/papers/gao.pdf

[34] V. A. Cloquell-Ballester, R. Monterde-Díaz and M. C. Santamarina-Siurana, "Indicators Validation for the Improvement If Environmental and Social Impact Quantitative Assessment," Environmental Impact Assessment Review, Vol. 26, No. 1, 2006, pp. 79-105. doi:10.1016/j.eiar.2005.06.002

[35] T. Gómez-Navarro, M. García-Melón, S. Acuña-Dutra and D. Díaz-Martín, "An Environmental Pressure Index Proposal for Urban Development Planning Based on the Analytic Process," Environmental Impact Assessment Review, Vol. 29, No. 5, 2009, pp. 319-329. doi:10.1016/j.eiar.2008.10.004

[36] SEMARNAT, "Informe de la Situación Ambiental del Medio Ambiente en México, 2003," Compendio de Estadísticas Ambientales, México, SEMARNAT, 2003.

[37] SEMARNAT, "Indicadores Básicos del Desempeño Ambiental de México. Edición 2008," Sistema Nacional de Indicadores Ambientales, SEMARNAT, México DF, 2008.

[38] C. R. López Pérez, "Experiencia del INEGI en la Elaboración de Indicadores Ambientales y de Desarrollo Sustentable," En: J. L. Blanco y M. L. R. Gamiño, Coord., Desarrollo de Indicadores Ambientales en México, IG-UNAM, México DF, 2008, pp. 27-55.

[39] Organisation for Economic Co-Operation and Development, "OECD Core Set of Indicators for Environmental
Performance Reviews," A Synthesis Report by the Group on the State of the Environment, OECD, Paris, 1993.

[40] INEGI, "Estadísticas del Medio Ambiente del Distrito Federal y Zona Metropolitana 2002," INEGI y SMAGDF, México DF, 2005.

[41] CONAGUA, "Estadísticas del Agua en México, Edición 2006," México, SEMARNAT, 2006.

[42] GF, "Gaceta Oficial de México 13-08-2003," Manual de la Organización General de la SEMARNAT, 2003. www.ordenjuridico.gob.mx/

[43] L. Pinter, P. Hardi and P. Bartelmus, "Sustainable Development Indicators: Proposals for the Way Forward," International Institute for Sustainable Development, Winnipeg, 2005.

[44] World Bank, "Expanding the Measure of Wealth: Indicators of Environmentally Sustainable Development," Environmentally Sustainable Development Studies and Monographs Series, No. 17, World Bank, Washington DC, 1997.

[45] EEA, "Environmental Indicators: Typology and Use in Reporting," EEA Internal Working Paper, 2003.

[46] Organisation for Economic Co-Operation and Development, "Environmental Indicators. A Preliminary Set. Organization for Economic Co-Operation and Development," Publication Service, OECD, Paris, 1991.

[47] R. M. Quiroga, "Indicadores de Sostenibilidad Ambiental y Desarrollo Sostenible: Estado del Arte y Perspectivas," N 16, CEPAL-Serie de Manuales, 2001.

[48] Bockstaller and P. Girardin, "How to Validate Environmental Indicators," Agricultural System, Vol. 76, No. 2, 2003, pp. 639-653. doi:10.1016/S0308-521X(02)00053-7

[49] R. Ortega, "El Sistema Nacional de Indicadores Ambientales (SNIA)," En: J. L. Blanco y M. L. R. Gamiño, Coord., Desarrollo de Indicadores Ambientales en México, IGUNAM, México DF, 2008, pp. 15-26.

[50] INE-SEMARNAP, “Avances en el Desarrollo de de Indicadores para la Evaluación del Desempeño Ambiental en México," 1997.

http://www.ine.gob.mx/indicadores/espanol/portada.htm

[51] INE-SEMARNAP, "Evaluación del Desempeño Ambiental. Reporte 2000,” SEMARNAP, México, 2000.

[52] SNIA, "Indicadores Básicos de Desempeño Ambiental," 2012.

http://app1.semarnat.gob.mx/dgeia/indicadores_2010_we b/indicadores_2010/00_conjunto/marco_conceptual3.httm 1

[53] J. López Blanco and M. L. Rodríguez Gamiño, Coord., "Desarrollo de Indicadores Ambientales en México," Colección: Geografía para el Siglo XXI. Serie: Libros de Investigación, Num.3, IGG-UNAM, México DF, 2008.

[54] L. B. Leopold, F. E. Clarke and B. B. H. Balsley, "A Procedure for Evaluating Environmental Impact," Geological Survey Circular 645, Washington DC, 1971.

[55] P. André, C. E. Delise and J. P. Revéret, "L'évaluation des Impacts sur 1'Environnement. Processus, Acteurs et Practique Pour un Développement Durable," 3e Edition, Presses Internaionales Politichnique, Quebec, 2010. 